\title{
FT-IR and CD Measurement of $Z$-Dehydrophenylalanine-Containing Peptides in the Solid State and in Solution
}

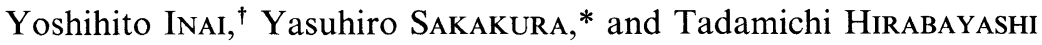 \\ Department of Environmental Technology and Urban Planning, Graduate School of Engineering, \\ Nagoya Institute of Technology, Gokiso-cho, Showa-ku, Nagoya 466-8555, Japan \\ * Department of Materials Science and Engineering, Nagoya Institute of Technology, \\ Gokiso-cho, Showa-ku, Nagoya 466-8555, Japan
}

(Received April 6, 1998)

\begin{abstract}
In sequential peptides Boc-(L-Leu- $\Delta$ Phe) ${ }_{n}-$ L-Leu-OMe I- $n, n=2-6$ (Boc, $t$-butoxycarbonyl; OMe, methoxy), peptides above $n=2$ were already found to form a stable right-handed $3_{10}$-helical structure in solution. In the present study, we focused on whether the above chain-length dependence on helical stability retains in the solid state, or not. For this purpose, FT-IR and CD spectra were measured for peptides I- $\boldsymbol{n}$ in the solid state and in solution. In FT-IR spectra of peptides I-3 to I-6 in $\mathrm{KBr}$ and in chloroform, two major peaks were observed in amide I absorption band: i.e., first peak at $1665-1655 \mathrm{~cm}^{-1}$ assigned to Leu residues in helical segments, and second peak at $1628-1625 \mathrm{~cm}^{-1}$ assigned to $\Delta$ Phe residues in helical segments. FT-IR pattern of peptide I-2 differed from those of peptides I-3 to I-6 in the solid state and in solution essentially. CD spectra of peptides I-n in KBr appeared clearly and strongly. Except for peptide I-2, peptides I-3 to I-6 in the solid state showed exciton couplets with a negative peak at longer wavelengths around $280 \mathrm{~nm}$ (assignable to $\Delta$ Phe residues), similarly to those in chloroform. The sign of split CD pattern corresponds to a right-handed arrangement of the transition moment: i.e., $\Delta \mathrm{Phe}$ residues are arranged regularly along a right-handed helical main chain. As a result, a stable helix is formed in the peptides above $n=2$ in the solid state as well as in solution.

KEY WORDS Solid-State Circular Dichroism Measurement / Fourier Transform Infrared Measurement / Sequential Oligopeptides / Z-Dehydrophenylalanine / Helical Conformation in Solid State / Chain-Length Effect /
\end{abstract}

$\alpha, \beta$-Dehydroamino acid (unsaturated) residues are naturally present in many peptides having biological activity as well as in some proteins. ${ }^{1-5}$ This type of residue shows inherent conformational properties due to its structural features, e.g., the planarity of $\mathrm{C}^{\alpha}=\mathrm{C}^{\beta}$ double bond and trigonal geometry of $\alpha$-carbon atom. As for $Z$-dehydrophenylalanine ( $\Delta \mathrm{Phe})$, the introduction of more than a $\Delta$ Phe residue into a peptide chain leads to $31^{-}$and/or $\alpha$-helical structures. ${ }^{6-20}$ Recently, we suggested that polypeptides containing $\Delta$ Phe and Pro residues, $\operatorname{poly}(\mathrm{X}-\Delta$ Phe-Pro $)$, take several $\beta$-helices as novel types of backbones, from conformational energy calculation and CD measurement. ${ }^{21}$ Thus, $\Delta$ Phe residue contains useful conformational properties for rational and novel design of peptides.

On the other hand, the conformational properties of $\Delta$ Phe residues have not been fully revealed. In our previous study, ${ }^{19,20}$ chain-length effects on helical conformations were investigated for sequential peptides I-n:<smiles>CCCC(NC(=O)C(=Cc1ccccc1)NOC(=O)C(CCC)NOC(C)=O)C(C)=O</smiles>

Boc-(L-Leu- $\Delta$ Phe $)_{n}$-L-Leu-OMe I- $n, n=2-6$

(Boc, $t$-butoxycarbonyl; OMe, methoxy)

As a result, peptides above $n=2$ were found to form a stable right-handed $3_{10}$-helical structure in solution.

In the present study, we focused on whether the above chain-length dependence on helical stability retains in the solid state, or not. For this purpose, FT-IR and CD

\footnotetext{
† To whom correspondence should be addressed.
}

measurement was carried out for peptides I- $\boldsymbol{n}$ in the solid state. For solid-state CD measurement, Formaggio et $a l^{22}$ recently reported that screw sense of helical oligopeptides containing chiral $\mathrm{C}^{\alpha}$-methylated residues to induce helical structures was successfully determined by the solid-state CD spectra. In these peptide, $p$-bromobenzamido chromophore was covalently linked to the $\mathrm{N}$-terminal position, and could be coupled with the peptide bond by dipole-dipole interaction, showing the splitting CD pattern around $240 \mathrm{~nm}$. According to exciton chirality method, ${ }^{23}$ the helical screw sense could be determined from the sign of exciton couplets. The solid-state $\mathrm{CD}$ technique should be suitable for peptides having absorption band above $230-240 \mathrm{~nm} .^{22}$ Thus, the method will be applied to conformational analysis of peptides I- $\boldsymbol{n}$ containing $\Delta \mathrm{Phe}$ residues that show intense absorption maxima around $280 \mathrm{~nm}$.

\section{EXPERIMENTAL}

\section{Materials \\ Peptides I-n prepared in the previous study $^{19}$ were} used.

\section{Measurement}

$\mathrm{CD}$ and UV spectra were recorded simultaneously using a JASCO J-600. According to ref 22, sample for solid-state $\mathrm{CD}$ measurement was prepared as follows. Peptide (ca. $0.2 \mathrm{mg})$ and dry $\mathrm{KBr}(100 \mathrm{mg})$ were finely ground, and the powder was pressed at $300 \mathrm{~kg} \mathrm{~cm}^{-2}$ for $10 \mathrm{~min}$ to prepare a clear and homogeneous disk of a $2 \mathrm{~cm}$ diameter. The disk held by a disk holder was placed normal to the light beam. To obtain the average signal of six signal-scan measurements, the disk was rotated 


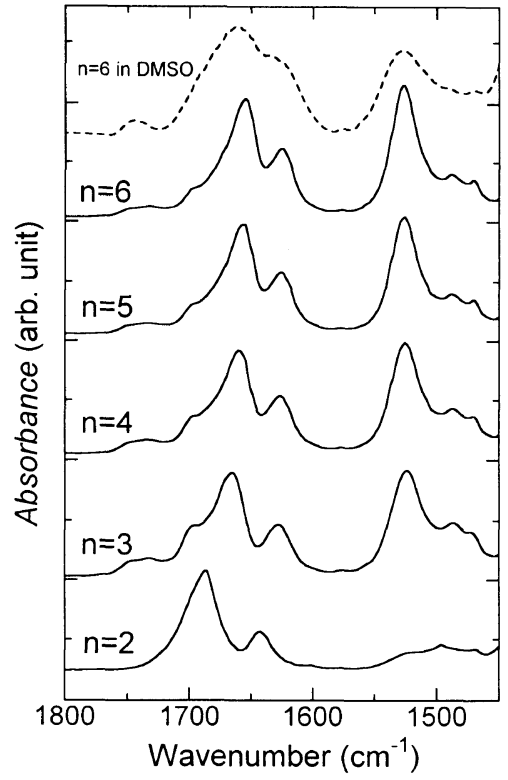

Figure 1. FT-IR spectra $\left(1800-1450 \mathrm{~cm}^{-1}\right)$ of peptides I-n $(n=2-6)$ in chloroform and peptide I-6 in DMSO.

manually at one every $60^{\circ}$, and then measured (at a rotation angle of $0^{\circ}, 60^{\circ}, 120^{\circ}, 180^{\circ}, 240^{\circ}$, and $300^{\circ}$ ). The spectrum of a $100 \% \mathrm{KBr}$ disk was used as blank. The ordinate of each $\mathrm{CD}$ spectrum in $\mathrm{KBr}$ was expressed in terms of ellipticity ( $\theta$ in $\mathrm{mdeg})$, when the corresponding absorption spectrum was normalized to a unity for the maximum absorbance $\left(A_{\max }\right)$ around $280 \mathrm{~nm}$ assignable to $\Delta$ Phe residues: i.e., $A_{\max }=1.0$. FT-IR spectra were recorded in $\mathrm{KBr}$ and in chloroform using a Nicolet FTIR spectrometer Impact 400 or a JASCO FT/IR-430 spectrometer. In $\mathrm{KBr}$, sample disk was prepared as mentioned above, and a $100 \% \mathrm{KBr}$ disk was used as blank. In chloroform, peptide solution of $5-10 \mathrm{mM}$ peptide concentration was prepared and transferred to $\mathrm{NaCl}$ cell with $0.1 \mathrm{~mm}$ cell length, and $100 \%$ chloroform was used as blank.

\section{RESULTS AND DISCUSSION}

\section{FT-IR Measurement}

Figure 1 shows FT-IR spectra of peptides I-n in chloroform around amide I and II regions, and Table I shows the corresponding peak positions in each spectrum. Little is known about the IR data of $\Delta$ Phecontaining peptides, since the properties of $\mathrm{C}=\mathrm{O}$ stretching band (amide I) for $\Delta \mathrm{Phe}$ residue is considered to differ from those in saturated amino acid residues due to resonance between $\mathrm{C}=\mathrm{O}$ and styryl groups in a $\Delta \mathrm{Phe}$ residue. Previously, ${ }^{19,20}$ we revealed that peptides I-3 to I-6 took a stable $33_{10}$-type helical conformation in solution, based on the ${ }^{1} \mathrm{H}$ NMR and CD spectroscopy, and on conformational energy calculation. Thus, FT-IR spectra of peptides I-3 to I-6 in chloroform (Figure 1) can be assigned to amide I and II bands for $3_{10}$-type helical structures of sequential peptides containing $\Delta \mathrm{Phe}$ residues. As the most striking feature of Figure 1 and Table I, two major peaks at amide I band were observed for peptides I-3 to I-6 in chloroform: first peak at $1665-1655 \mathrm{~cm}^{-1}$, and second one at $1628-1625 \mathrm{~cm}^{-1}$. The first peak position agrees with that of amide I band

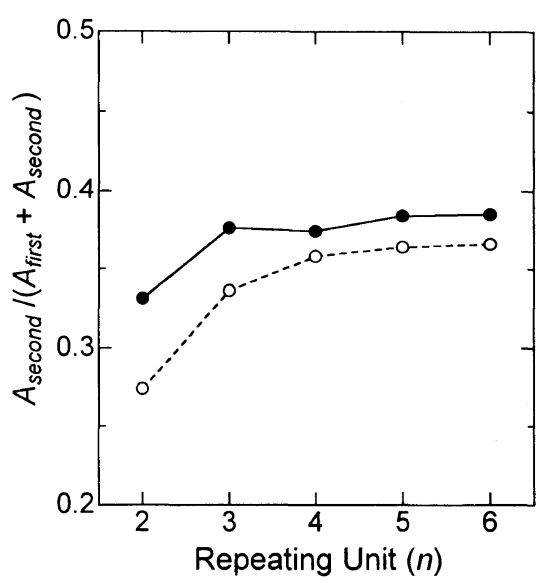

Figure 2. The relation between repeating unit $(n)$ and the contribution of second peak in amide $\mathrm{I}$ band in chloroform $(\mathrm{O})$ and in $\mathrm{KBr}(\mathrm{O})$ : $A_{\text {first }}$, maximum absorbance of first peak; $A_{\text {second }}$, maximum absorbance of second peak in the amide I band.

in a $33^{-}$or $\alpha$-helix of $\alpha$-aminoisobutyric acid (Aib)containing peptides: e.g., $1665 \mathrm{~cm}^{-1}$ for $3_{10}$-helix of poly(Aib), ${ }^{24} 1666-1662 \mathrm{~cm}^{-1}$ for $3_{10}$-helix of $\mathrm{Z}-(\mathrm{Aib})_{n}-$ $\mathrm{O} t \mathrm{Bt}(n=8-10: \mathrm{Z}$, benzyloxycarbonyl; O $t \mathrm{Bt}, t$-butoxy) in $\mathrm{CDCl}_{3},{ }^{25} 1662 \mathrm{~cm}^{-1}$ for $3_{10}$-helix of and $1659 \mathrm{~cm}^{-1}$ for $\alpha$-helix of $\mathrm{Z}$-(Aib-L-Ala) $)_{5}-\mathrm{OMe}$ in $\mathrm{CDCl}_{3},{ }^{25}$ and

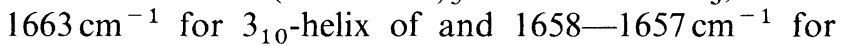
$\alpha$-helix of $\mathrm{Z}$-(L-Ala-Aib) $)_{5}-\mathrm{L}-\mathrm{Ala}-\mathrm{OMe}$ in $\mathrm{CDCl}_{3} \cdot{ }^{25}$

On the other hand, the second peak in the amide I band was not observed for the above Aib-containing peptides. In peptides I-3 to I-6, the intensity of second peak was comparable to that of first peak, and did not tend to decrease with increasing the chain-lengths, as shown in Figure 2. This means that the second peak is not ascribed to irregular parts other than helical segments. Such first and second peaks were also seen in $3_{10}$-type helical peptides containing $\Delta$ Phe residues: i.e., Boc-(L-Ala- $\Delta$ Phe-Aib $)_{m}$-OMe $(m=2-4)^{26}$ showed 1655 and $1620 \mathrm{~cm}^{-1}$ for peptide $m=4,1655$ and 1620 $\mathrm{cm}^{-1}$ for peptide $m=3$, and 1660 and $1625 \mathrm{~cm}^{-1}$ for peptide $m=2$ in the amide I regions. Obviously, the second peak emerged when $\Delta \mathrm{Phe}$ residues are introduced to helical Aib-containing peptides, which show no second peaks. Therefore, the second peak should be assigned to $\mathrm{C}=\mathrm{O}$ stretching band of $\Delta \mathrm{Phe}$ residues incorporated into helical peptides. Compared with saturated amino acid residues, $\mathrm{C}=\mathrm{O}$ stretching band in a $\Delta$ Phe residue is expected to be shifted to lower wavenumbers due to contribution of resonance between $\mathrm{C}=\mathrm{O}$ and styryl groups within a $\Delta \mathrm{Phe}$ residue:

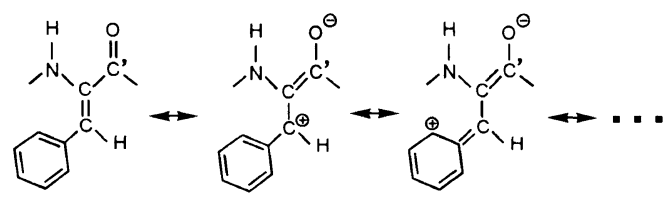

The above resonance was experimentally evidenced: The $C^{\alpha}-C^{\prime}$ length of $\Delta P$ he residues is $1.50 \AA$, slightly less than the corresponding distance of $1.53 \AA$ in saturated amino acid residues. ${ }^{6,27}$ Also, the value of $\mathrm{C}^{\prime}=\mathrm{O}$ bond $(1.231 \AA)$ in $\Delta$ Phe residues is slightly larger than the value found in Phe residues $(1.203 \AA) .^{6,27}$ In fact, the second peak in the amide I appeared at lower wavenumbers than the first peak, as shown in Figure 1. 
Table I. FT-IR data of peptides I-n in solution and in the sold state

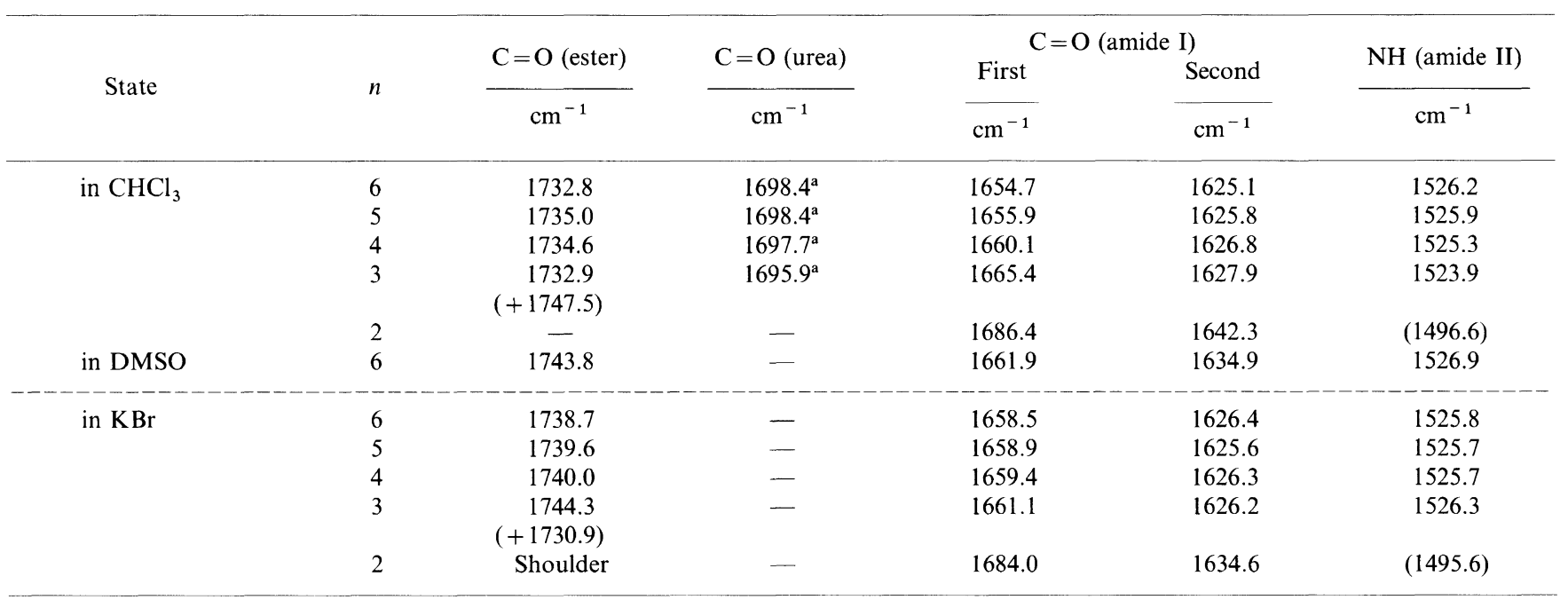

${ }^{\text {a }}$ As a shoulder of amide I band.

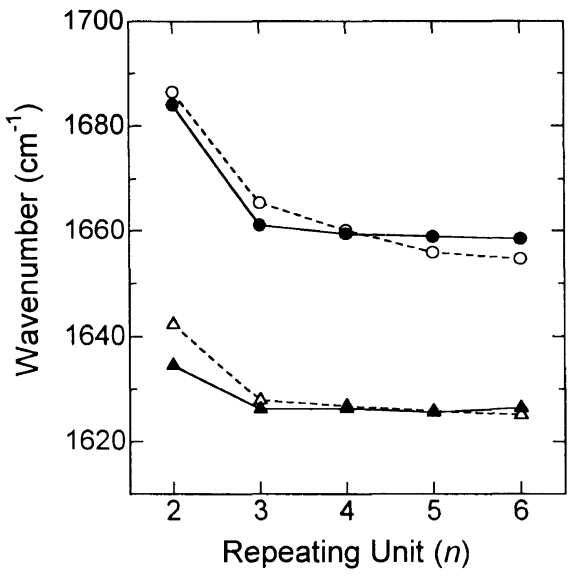

Figure 3. The relation between repeating unit $(n)$ and peak position in the amide $\mathrm{I}$ band: first $(O)$ and second $(\triangle)$ peaks in chloroform, and first $(\mathbf{)})$ and second $(\boldsymbol{\Delta})$ peaks in $\mathrm{KBr}$.

It should be concluded that the first peak is assigned to Leu residues in helical segments, and the second peak to $\Delta \mathrm{Phe}$ residues in helical segments. On the other hand, amide II band appeared at $1526-1524 \mathrm{~cm}^{-1}$ as single peak. The position was slightly shifted to lower wavenumbers than those of Aib-containing peptides cited above: $1533-1532 \mathrm{~cm}^{-1}$ for $\mathrm{Z}-(\mathrm{Aib})_{n}-\mathrm{O} t \mathrm{Bt}(n=8-10)$, $1536 \mathrm{~cm}^{-1}$ for $\mathrm{Z}-(\mathrm{Aib}-\mathrm{L}-\mathrm{Ala})_{5}-\mathrm{OMe}$ and $\mathrm{Z}-(\mathrm{L}-\mathrm{Ala}-$ Aib) ${ }_{5}-$ L-Ala-OMe. $^{25}$

As shown in Figure 1, FT-IR pattern of peptide I-2 differed from those of peptides I-3 to I-6 essentially. Figure 3 shows the relation between repeating unit $(n)$ and peak position in the amide I band. The first and second peak positions were remarkably shifted to lower wavenumbers in peptides $\mathbf{I}-\mathbf{2}$ to $\mathbf{I}-\mathbf{3}$, and slightly decreased in peptides I-3 to I-6. Neither first $\left(1686 \mathrm{~cm}^{-1}\right)$ nor second $\left(1642 \mathrm{~cm}^{-1}\right)$ peak positions in peptide $\mathbf{I - 2}$ correspond to those characteristic of amide I band of $3_{10^{-}}$and/or $\alpha$-helical chain $\left(1665-1659 \mathrm{~cm}^{-1}\right){ }^{25}$

Accordingly, peptide I-2 contains a conformation other than helix, and a stable helix should be formed in peptides above $n=2$. This conclusion derived from the FT-IR data agreed well with those obtained from ${ }^{1} \mathrm{H}$ NMR and CD spectroscopy, and conformational energy

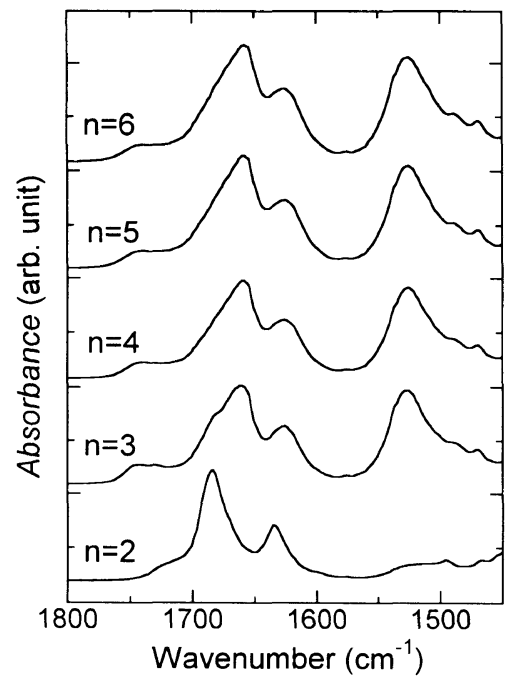

Figure 4. FT-IR spectra $\left(1800-1450 \mathrm{~cm}^{-1}\right)$ of peptides I-n $(n=2-6)$ in $\mathrm{KBr}$.

calculation. ${ }^{19,20}$ In addition, the first peak position was slightly shifted to lower wavenumbers in peptides I-3 to I-6, suggesting the presence of not only a $3_{10}$-helix, but a mixture of $3_{10^{-}} / \alpha$-helices.

Also, Figure 1 shows FT-IR spectra of peptides I-6 in dimethyl sulfoxide (DMSO) around amide I and II regions, and Table I shows the corresponding peak positions in each spectrum. Previously, ${ }^{20}$ peptide I-6 in DMSO was found to show much smaller CD intensity than in $\mathrm{CHCl}_{3}$, which will be shown in Figure 7. This indicates that peptide I-6 took disordered (random coil) conformations in DMSO. Thus, FT-IR data in DMSO can be assigned to amide bands of peptide I-6 in random coil conformations. For amide I band, both first and second peaks in DMSO were shifted to higher wavenumbers $\left(7-10 \mathrm{~cm}^{-1}\right)$ than those in $\mathrm{CHCl}_{3}$, while the same peak positions for amide II band were seen in $\mathrm{CHCl}_{3}$ and in DMSO.

Figure 4 shows FT-IR spectra of peptides I- $\boldsymbol{n}$ in $\mathrm{KBr}$ around amide I and II regions, and Table I shows the corresponding peak positions in each spectrum. Essentially, FT-IR data of peptides I-n in the solid state resem- 


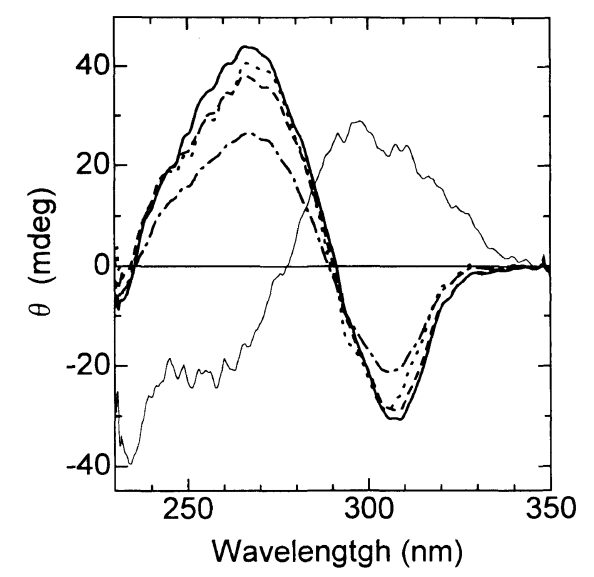

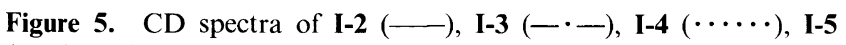
$(--)$, and $\mathbf{I}-6(-)$ around $280 \mathrm{~nm}$ in $\mathrm{KBr}$.

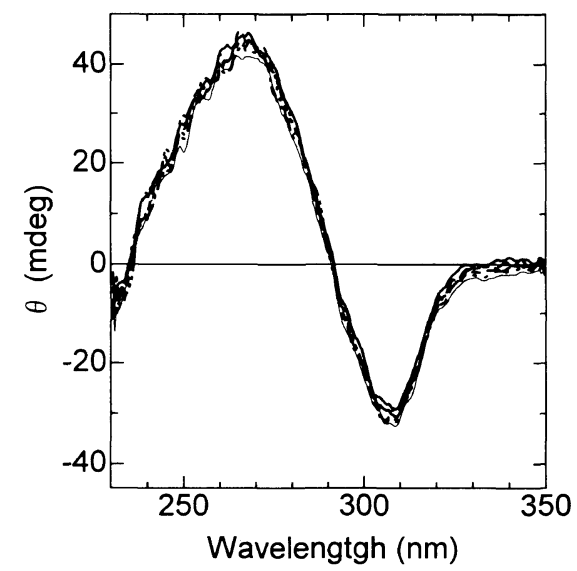

Figure 6. $\mathrm{CD}$ spectra of peptide $\mathbf{I - 6}$ in $\mathrm{KBr}$ with a rotation angle of $0^{\circ}(-), 60^{\circ}(--), 120^{\circ}(\cdots \cdots), 180^{\circ}(-\cdot-), 240^{\circ}(-\cdots-)$, and $300^{\circ}(-)$.

bled those in solution. Also, similar chain-length dependence on the peak positions was seen in the solid state and in solution, as shown in Figure 3 and Table I. Thus, it should be concluded that peptide $\mathbf{I}-\mathbf{2}$ does not take a stable helix, but a stable helix is formed in peptides above $n=2$ also in the solid state.

\section{Measurement}

Peptides containing $\Delta \mathrm{Phe}$ residues show intense absorption maxima around $220 \mathrm{~nm}$ and around $280 \mathrm{~nm}$. The former absorption band precludes a far-UV CD analysis to usually reveal conformations of peptides or proteins. On the other hand, the latter absorption band has been assigned to charge transfer from the highest occupied orbital localized on styryl moiety to the vacant orbital of carbonyl group in a $\Delta$ Phe residue. ${ }^{28,29}$ The transition moment was estimated from molecular orbital calculation to lie on the styryl-carbonyl line. ${ }^{26}$ Thus, most of peptides containing more than a $\Delta \mathrm{Phe}$ residue will show exciton-type $\mathrm{CD}$ couplets, of which the sign and amplitude give useful information for conformational analysis.

Figure 5 shows CD spectra of peptides I-2 to I-6 around $280 \mathrm{~nm}$ in $\mathrm{KBr}$. All CD spectra appeared clearly and strongly, and $\mathrm{CD}$ spectrum of each sample did not change with every $60^{\circ}$ rotation essentially, e.g., as shown in Figure 6 for peptide I-6. Also, $\Delta$ Phe-containing peptides

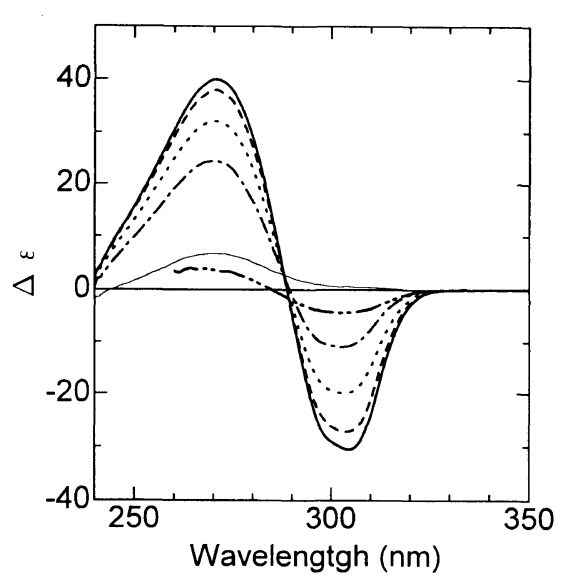

Figure 7. $\mathrm{CD}$ spectra of $\mathbf{I}-2(-), \mathbf{I}-\mathbf{3}(-\cdot-), \mathbf{I}-\mathbf{4}(\cdots \cdots)$, I-5 $(--)$, and I-6 (-) in chloroform, and I-6 (- - - ) in DMSO around $280 \mathrm{~nm}$.

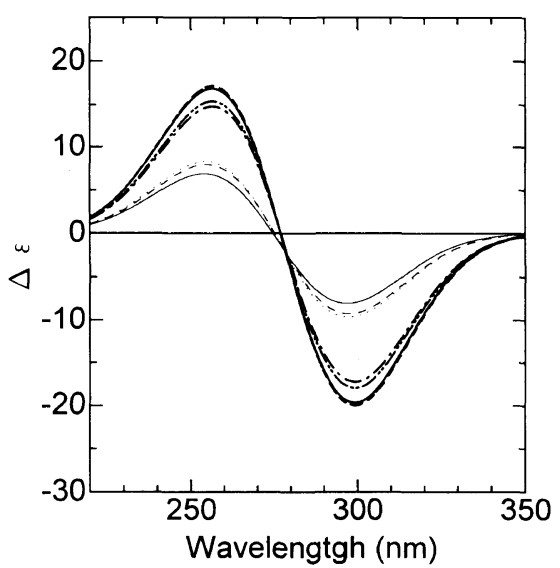

Figure 8. Theoretical $\mathrm{CD}$ spectra of peptide $\mathbf{I}-\mathbf{4}$ in the helices (1: $\left.\phi=-44^{\circ}, \quad \psi=-33^{\circ} ;-\right), \quad\left(2: \phi=-54^{\circ}, \quad \psi=-28^{\circ} ;---\right)$, (3: $\left.\phi=-71^{\circ}, \psi=-18^{\circ} ; \cdots \cdots\right),\left(4: \phi=-53^{\circ}, \psi=-36^{\circ} ;-\cdot-\right)$, (5: $\left.\phi=-60^{\circ}, \psi=-30^{\circ} ;-\cdots-\right),\left(6: \phi=-53^{\circ}, \psi=-52^{\circ} ;-\right.$, , (7: $\left.\phi=-57^{\circ}, \psi=-47^{\circ} ;---\right)$, and $\left(8: \phi=-63^{\circ}, \psi=-42^{\circ} ; \cdots \cdots\right)$.

without chiral residue(s) (e.g., Boc-(Aib- $\Delta \mathrm{Phe})_{4}-\mathrm{Aib}-$ $\mathrm{OMe}$ ) in $\mathrm{KBr}$ gave no signals (only a noisy base line). Accordingly, CD spectra of peptides I-2 to I-6 were not caused by artifacts such as light-scattering. Except for peptide I-2, peptides I-3 to I-6 in the solid state showed exciton couplets with a negative peak at longer wavelengths, similarly to those in chloroform as shown in Figure $7 .{ }^{19}$ By applying the exciton chirality method ${ }^{23}$ to the present system, the split CD pattern corresponds to a right-handed arrangement of the transition moment: i.e., $\Delta$ Phe residues are arranged regularly along a right-handed helical main chain. This is also supported by theoretical $\mathrm{CD}$ spectra calculated based on excitonchirality method. ${ }^{23}$ Figure 8 shows theoretical CD spectra of peptide I-4 in five right-handed $3_{10}$-type $(4 \rightarrow 1$ hydrogen bonded) helices (1) - (5) and three right-handed $\alpha$-type $(5 \rightarrow 1$ hydrogen bonded) helices (6)-(8): (1) $\phi=-44^{\circ}, \psi=-33^{\circ 30} ;$ (2) $\phi=-54^{\circ}, \psi=-28^{\circ 31}$; (3) $\phi=-71^{\circ}, \psi=-18^{\circ 32} ;$ (4) $\phi=-53^{\circ}, \psi=-36^{\circ 33}$; (5) $\phi=-60^{\circ}, \psi=-30^{\circ 34,35}$; (6) $\phi=-53^{\circ}, \psi=-52^{\circ 36}$; (7) $\phi=-57^{\circ}, \psi=-47^{\circ 37} ;(8) \phi=-63^{\circ}, \psi=-42^{\circ} .^{38}$ In all theoretical spectra, exciton couplets with a negative peak at longer wavelengths were seen for peptides I-4 in right-handed helices. For the other peptides, similar 
theoretical CD patterns were obtained.

On the other hand, peptide I-2 in the solid state showed exciton-couplets of the opposite sign, while it in chloroform showed highly distorted exciton couplets or positive signals. The change of CD pattern with environments (in the solid state and in solution) means that peptide I-2 does not take a stable helix, but a stable helix is formed in peptides above $n=2$ in the solid state as well as in solution, which agrees with the results in the preceding section.

\section{CONCLUSIONS}

First, FT-IR and CD spectra were measured for sequential oligopeptides containing $\Delta$ Phe residues I- $\boldsymbol{n}$ in the solid state and in solution. As a result, a stable helix is formed in peptides above $n=2$ in the solid state as well as in solution. Namely, the chain-length dependence on helical stability retains in the solid state.

Second, FT-IR data were presented here for $\Delta$ Phecontaining oligopeptides in helical conformations. Unlike helical oligopeptides consisting of saturated amino acid residues, two major peaks were observed in amide I band: i.e., first peak at $1665-1655 \mathrm{~cm}^{-1}$ assigned to saturated residues in helical segments, and second peak at 1628 $1625 \mathrm{~cm}^{-1}$ assigned to $\Delta$ Phe residues in helical segments.

Finally, solid-state CD measurement could be applied to $\Delta$ Phe-containing peptides to reveal their conformations in the solid state. Of course, X-ray crystallographic analysis should be suitable for obtaining their complete conformations. However, the solid-state CD technique will be effective and useful for readily obtaining preliminary conformational data on not only $\Delta$ Phe-containing peptides, but also on (poly)peptides containing aromatic chromophores such as arylalanines, ${ }^{39}$ particularly on such (poly)peptides difficult to crystallize.

Acknowledgments. We express our sincere gratitude to Professor M. Kawai in Department of Applied Chemistry, Nagoya Institute of Technology for the use of $\mathrm{CD}$ apparatus.

\section{REFERENCES}

1. K. Noda, Y. Shimohigashi, and N. Izumiya, in "The Peptides," Vol. 5, E. Gross and J. Meienhofer, Ed., Academic Press, New York, N.Y., 1983, pp 286-339.

2. E. Gross and J. L. Morell, J. Am. Chem. Soc., 89, 2791 (1967).

3. H. Allgaier, G. Jung, R. G. Werner, U. Schneider, and H. Zaehner, Eur. J. Biochem., 160, 9 (1986).

4. I. L. Givot, T. A. Smit, and R. H. Abeles, J. Biol. Chem., 244, 6341 (1969)

5. R. B. Wickner, J. Biol. Chem., 244, 6550 (1969).

6. R. Jain and V. S. Chauhan, Biopolymers (Peptide Science), 40, 105 (1996).

7. O. Pieroni, A. Fissi, R. M. Jain, and V. S. Chauhan, Biopolymers,
38, 97 (1996).

8. S. N. Mitra, S. Dey, S. Karthikeyan, and T. P. Singth, Biopolymers, 41, 97 (1997).

9. K. R. Rajashankar, S. Ramakumar, and V. S. Chauhan, J. Am. Chem. Soc., 114, 225 (1992).

10. O. Pieroni, A. Fissi, C. R. Pratesi, P. A. Temussi, and F. Ciardelli, J. Am. Chem. Soc., 113, 6338 (1991).

11. M. R. Ciajolo, A. Tuzi, C. R. Pratesi, A. Fissi, and O. Pieroni, Biopolymers, 30, 911 (1990)

12. K. K. Bhandary and V. S. Chauhan, Biopolymers, 33, 209 (1993).

13. B. Padmanbhan and T. P. Singh, Biopolymers, 33, 613 (1993).

14. V. S. Chauhan, K. Uma, P. Kaur, and P. Balaram, Biopolymers, 28, 763 (1989)

15. M. R. Ciajoro, A. Tuzi, C. R. Pratesi, A. Fissi, and O. Pieroni, Biopolymers, 32, 717 (1992).

16. A. Gupta, A. Bharadwaj, and V. S. Chauhan, J. Chem. Soc., Perkin Trans. 2, 1911 (1990).

17. A. Tuzi, M. R. Ciajolo, G. Guarino, P. A. Temussi, A. Fissi, and O. Pieroni, Biopolymers, 33, 1111 (1993).

18. O. Pieroni, A. Fissi, C. Pratesi, P. A. Temussi, and F. Ciardelli, Biopolymers, 33, 1 (1993).

19. Y. Inai, K. Hasegawa, T. Hirabayashi, and K. Yokota, Polym. J., 28, 238 (1996).

20. Y. Inai, K. Hasegawa, T. Hirabayashi, and K. Yokota, Polym. J., 28, 440 (1996).

21. Y. Inai, Y. Sakakura, and T. Hirabayashi, Polym. J., 29, 649 (1997).

22. F. Formaggio, M. Crisma, C. Toniolo, and J. Kamphuis, Biopolymers, 38, 301 (1996)

23. N. Harada, S. L. Chen, and K. Nakanishi, J. Am. Chem. Soc., 97, 5345 (1975).

24. A. M. Dwiedi, S. Krimm, and B. R. Malcolm, Biopolymers, 23, 2025 (1984).

25. D. F. Kennedy, M. Crisma, C. Toniolo, and D. Chapman, Biochemistry, 30, 6541 (1991).

26. Y. Inai, T. Ito, T. Hirabayashi, and K. Yokota, Biopolymers, 33, 1173 (1993)

27. E. Benedetti, in "Peptides, Proceedings of the Fifth American Peptide Symposium," M. Goodman and J. Meienhofer, Ed., John Wiely, New York, N.Y., 1977, pp 257-273.

28. O. Pieroni, A. Fissi, S. Merlino, and F. Ciardelli, Isr. J. Chem., 15, 22 (1976/1977).

29. O. Pieroni, G. Montagnoli, A. Fissi, S. Merlino, and F. Ciadrelli, J. Am. Chem. Soc., 97, 6820 (1975).

30. B. R. Malcolm and M. D. Walkinshaw, Biopolymers, 25, 607 (1986)

31. C. Toniolo, G. M. Bonora, A. Bavoso, E. Benedetti, B. Di Blasio, V. Pavone, and C. Pedone, Macromolecules, 19, 472 (1986).

32. D. J. Barlow and J. M. Thronton, J. Mol. Biol., 201, 601 (1988).

33. E. E. Hodgkin, J. D. Clark, K. R. Miller, and G. R. Marshall, Biopolymers, 30, 533 (1990).

34. Y. Paterson, S. M. Rumsey, E. Benedetti, G. Nemethy, and H. A. Scheraga, J. Am. Chem. Soc., 103, 2947 (1981).

35. G. N. Ramachandran and V. Sasisekharan, Adv. Protein Chem., 23, 238 (1968).

36. S. J. Leach, G. Nemethy, and H. A. Scheraga, Biopolymers, 4, 887 (1966).

37. S. Arnott and A. J. Wonacott, J. Mol. Biol., 21, 317 (1966)

38. T. Blundell, D. Barlow, N. Borkakoti, and J. Thornton, Nature, 306, 218 (1983).

39. M. Sisido, Y. Inai, and Y. Imanishi, in "Fundamental Investigations on the Creation of Biofunctional Materials," S. Okamura, T. Tsuruta, Y. Imanishi, and J. Sunamoto, Ed., Kagaku-Dojin, Kyoto, Japan, 1991, pp 183-196. 